\title{
A proposed impact assessment method for genetically modified plants (AS-GMP Method)
}

\author{
Katia Regina Evaristo de Jesus-Hitzschky ${ }^{a}$,* , José Maria F.J. da Silveira ${ }^{b}$ \\ a Embrapa Environment, Rodovia SP 340 km 127,5 CP 69 CEP 13820-000 Jaguariuna, SP, Brazil \\ ${ }^{\mathrm{b}}$ Agriculture and Environmental Research Center, NEA-Institute of Economics, University of Campinas, SP, Brazil
}

\section{A R T I C L E I N F O}

Article history:

Received 13 October 2008

Received in revised form 10 February 2009

Accepted 10 February 2009

Available online 10 April 2009

\section{Keywords:}

Biotechnology impacts

Genetically modified plants rapid appraisal

Impact assessment

Technological forecasting

\begin{abstract}
A B S T R A C T
An essential step in the development of products based on biotechnology is an assessment of their potential economic impacts and safety, including an evaluation of the potential impact of transgenic crops and practices related to their cultivation on the environment and human or animal health. The purpose of this paper is to provide an assessment method to evaluate the impact of biotechnologies that uses quantifiable parameters and allows a comparative analysis between conventional technology and technologies using GMOs. This paper introduces a method to perform an impact analysis associated with the commercial release and use of genetically modified plants, the Assessment System GMP Method. The assessment is performed through indicators that are arranged according to their dimension criterion likewise: environmental, economic, social, capability and institutional approach. To perform an accurate evaluation of the GMP specific indicators related to genetic modification are grouped in common fields: genetic insert features, GM plant features, gene flow, food/feed field, introduction of the GMP, unexpected occurrences and specific indicators. The novelty is the possibility to include specific parameters to the biotechnology under assessment. In this case by case analysis the factors of moderation and the indexes are parameterized to perform an available assessment.
\end{abstract}

(C) 2009 Elsevier Inc. All rights reserved.

\section{Introduction}

An essential step for the development of a genetically modified plant (GMP) is the assessment of its safety. This procedure evaluates all possible influences of the plant and practices related to its cultivation on the environment and on human or animal health. This is accomplished through adequate comparisons between the target of genetic manipulations and organisms with similar traits, for example, wild genotypes of the plant used to produce the GMP. This evaluation is performed by impact analysis.

The GMP impact assessment, in general, may be a helpful tool for decision-making process. Search engines and systemized data compression tools, which allow the generation of traceable conclusions, are keyelements to assure that the decision-making process culminates in the appropriate biotechnology management, with the best resources and results. This study proposes a methodological system to evaluate the impacts of biotechnologies, providing information organized according to criteria and indicators of several areas where the impact can be perceived in a direct or indirect manner: social, economic, environmental, institutional and capacity development (General Assessment); genetic insert features, GM plant features, gene flow, food/feed field,

\footnotetext{
* Corresponding author. Tel.: +55 19 33112641; fax: +55 1933112640 E-mail address: katiareg@cnpma.embrapa.br (K.R.E. Jesus-Hitzschky).
}

introduction of the GMP, unexpected occurrences and specific indicators (Technical Assessment).

The proposed system is based on previous methods of risk analysis and impact assessment, such as GMP-RAM METHOD - Risk Assessment Method for Genetically Modified Plants (Jesus et al., 2006), INOVA-tec System - Impact Assessment System for Technological Innovation (Jesus-Hitzschky, 2007) and Environmental Impact Assessment methods utilized during ISO 14000 implementation. Many validated issues or parameters of analysis described in previous reports (EFSA, 2006; OCDE, 2005; FAO, 2004; Conner et al., 2003; NAS, 2002) were also considered. The AS-GMP Method allows the evaluator to point out the specific parameters to evaluate his/her biotechnology enabling the analysis of each particular case, so that the GMP can be applied in a responsible and sensible way.

This information is organized into three tools: (1) worksheets to compile Prospective Range, through the Significance Index; (2) indicators worksheets to compile an Impact Level Performance defined by the Magnitude Index. Finally the combination of both Indexes (Significance $\times$ Magnitude) designs the (3) Matrix of Impact that is built by the General Impact Value. The AS-GMP Method works as a guide pointing to indicators which should be analyzed and to the components that may have some importance in the evaluation hence the method contributes to reduce subjectivity.

In this way it allows, as a whole, the reduction of negative impacts, and the best use of resources for GMP introduction so that the prevention and mitigation of environmental damages can be achieved. 


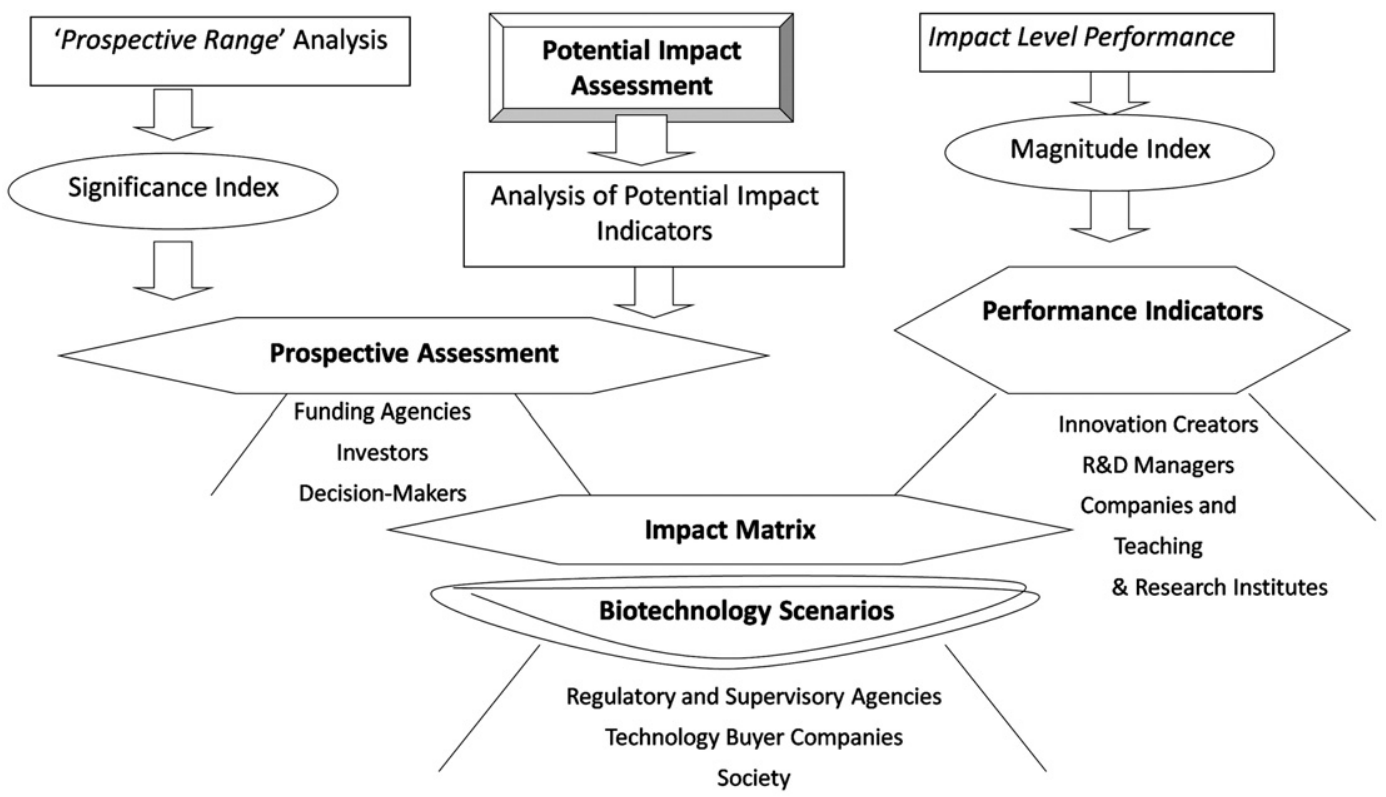

Fig. 1. Structure of AS-GMP Method.

All activities related to commercial release, field trial tests, greenhouse experiments, or even lab assays with GMP are evaluated by AS-GMP method. Therefore, the method can be used throughout GMP development, from the researcher during new trait search to the regulators during assessment for market clearance. Obviously, the exchange of information and experience among all involved parts allows an accurate analysis of GMP safety. The method can be used by program and project evaluators, managers and also regulatory and supervisory agencies. To allow a better comprehension of this system, it is presented in a digital format $^{1}$ (AS-GMP Method v.1.0. Software) and its three tools are linked so that the user can fill the information in the worksheets and automatically observe the results in tables, graphics and matrices. It also presents a conclusive report.

\subsection{Transgenic crop environment and AS-GMP Method}

The main purpose of the method is to improve the rapid evaluation of possible impacts of the commercialization of transgenic crops, compatible with the existing restraints put on costs and time by the situation of the majority of Biotechnology Safety Committees, mostly in developing countries. ${ }^{2}$ However, the method allows evaluating exante and ex-post the development of GMP on the market, contributing to the concept of sustainability (Fig. 1). The AS-GMP Method has a low cost, but allows a wide evaluation, showing the indicators at several levels. It is also able to act directly within the scope of research institutions and biotechnology companies, and to indirectly promote the discussion of proposition of new biotechnology policies. A spin-off of AS-GMP Method is the adequacy or generation of public and

\footnotetext{
${ }^{1}$ Soon available for download at the website of Embrapa Meio Ambiente: http:// www.cnpma.embrapa.br/forms/as_gmp.php3.

2 The Multicriteria Analysis can be seen as a more sophisticated alternative to rapid appraisal approaches. According to Zackiewicz (2005), Multicriteria Analysis framework has been developed as an aid for evaluating decisions, choices that could provide a basis for ex-ante selection of projects related to biotechnology and the diffusion of GMP. Though, it has an impact evaluation perspective, hence, an ex-post approach. However, the two kinds of evaluation must be used in their own time for a bette possible achievement on the research effort allocation, improving public research portfolio choices. This kind of approach uses a specifically developed methodology to integrate economic with environmental, social, and building capability dimensions. The progress of the assessment of these new frameworks have allowed to evaluate problems raised on the treatment of economic impacts, when one moves away from the Cost-benefit analysis and Cost-effectiveness to a more comprehensive framework.
}

Research \& Development policies more suitable to the innovative process, in a way that the comprehensive assessment of biotechnology allows a rational environmental management allied with the accountability of clearness in the results.

Fig. 1 is a schema of AS-GMP Method, showing its potentiality of use by several actors, interests and assessment timing. In case the assessment has a prospective interest the analysis must be done exante the technology use, focusing on the 'Prospective Range' and illustrating its focus on potential impacts assessment.

It is possible to point out why probably there would be more interest in this kind of analysis: funding agencies, investors and decision-makers, in order to decide among a project portfolio or what is the range of a funded innovation. The assessment ex-post of the innovation development foresees the assessment of all indicators, gathered in accordance with the assessment criteria on its fields and which analysis allows the clarification of 'Impact Level Performance'. The analysis of the range or prospective assessment and the choice of the Indicators of Performance in order to prepare the structure of the impact matrix and therefore to elaborate the 'GMP Scenario' is part of general impact assessment. The general analysis of impacts and GMP scenario must be the focus of the analysis made by regulatory and supervisory agencies, technology buyer companies and society on the whole.

The cost of regulatory release and compliance is already the most important roadblock for public goods research projects in this field (De Greef, 2004). Alternative approaches to regulate new crop biotechnologies could be less expensive, but to date the private and social costs of the current regulatory system have not been analyzed or measured, let alone compared with alternatives (Kalaitzandonakes et al., 2007). The AS-GMP Method/Software will be available cost-free at Embrapa Meio Ambiente (Environment) website. It will impact favorably the biosafety assessments for regulatory submissions since the method indicates the most important parameters that have to be addressed in researches or experiments, avoiding data duplication which gathers needless requirements and wastes biosafety assessment money.

\section{The description of the AS-GMP Method}

\subsection{Biotechnology characterization}

In order to carry out biotechnology assessment first of all it is recommended to perform the GMP characterization in order to assure 
Table 1

Moderation factors for Significance Index $\mathrm{Gen}_{\mathrm{G}}$ estimate.

\begin{tabular}{|c|c|c|c|c|c|}
\hline Extent & $\begin{array}{l}\text { Weight } \\
\text { values }\end{array}$ & Scope & $\begin{array}{l}\text { Possible } \\
\text { values }\end{array}$ & Influence & $\begin{array}{l}\text { Possible } \\
\text { values }\end{array}$ \\
\hline $\begin{array}{l}\text { Punctual } \\
\text { Local } \\
\text { Regional } \\
\text { National } \\
\text { International }\end{array}$ & $\begin{array}{l}1 \\
2 \\
3 \\
4 \\
5\end{array}$ & $\begin{array}{l}\text { Environment } \\
\text { Human health } \\
\text { Research/product quality } \\
\text { Social } \\
\text { Economic } \\
\text { Political } \\
\text { Legal }\end{array}$ & $\begin{array}{l}1,2 \text { and } 3 \\
1,2 \text { and } 3 \\
1,2 \text { and } 3 \\
1,2 \text { and } 3 \\
1,2 \text { and } 3 \\
1,2 \text { and } 3 \\
1,2 \text { and } 3\end{array}$ & $\begin{array}{l}\text { Indirect } \\
\text { Direct } \\
\text { Null }\end{array}$ & $\begin{array}{l}1 \\
2 \\
0\end{array}$ \\
\hline
\end{tabular}

Table 2

Data of the genetic insertion safety.

\begin{tabular}{l}
$\begin{array}{l}\text { Data/tests previously } \\
\text { performed }\end{array}$ \\
\cline { 2 - 3 }
\end{tabular}

a proper assessment report and hereby attendance and monitoring of its application performance.

The necessary information to collect the most relevant data in order to assure acuity of assessment is presented below. This information is presented on the first page of AS-GMP Software.

\subsection{Information about GM plant}

2.2.1. Description of the trait(s) and characteristics which have been introduced or modified

A description of the trait and the changes it produces on the plant phenotype is required (EFSA, 2006). Phenotypic modifications should be quantified in relation to the comparable non-GM plant. The targets of the trait should be identified as well as the sensitivity of nontargets. The purposes of the genetic modification and the uses of the GM crop should be described together with changes in the crop composition, management, cultivation, deployment, geographic range and end use.

\subsubsection{Information on the sequences actually inserted or deleted}

Applicants should provide information on (EFSA, 2006): (a) the size and number of copies of all detectable inserts, both complete and partial;

Table 3

Localization of the plantation.

\begin{tabular}{lll}
\hline Localization of the site where the GMP will grow & Yes & No \\
\hline Center of diversity of the recipient species & -1 & 0 \\
Center of origin of the recipient species & -2 & 0
\end{tabular}

Table 4

Reproductive characteristic of the recipient.

\begin{tabular}{lc}
\hline Reproductive characteristic of the recipient & Weight \\
\hline Autogamic & +3 \\
Cross pollination & -3 \\
Intermediary group & 0
\end{tabular}

(b) the organization of the inserted genetic material at the insertion site and methods used for the characterization; (c) in case of deletion(s), size and function of the deleted region(s); and (d) sub-cellular location(s) of insert(s) (nucleus, chloroplasts, mitochondria maintained in a nonintegrated form) and methods for its determination.

\subsubsection{Genomic databases for the crop species}

With regard to flanking sequences in general the GMO panel is aware that comparative sequence analysis may not always be possible due to limited genomic databases for the crop species in question.

\subsubsection{Methods used for expression analysis}

The methods used for the analysis of gene and protein expression must be provided.

\subsubsection{Donor features}

\subsubsection{Recipient feature: rate and distance of outcrossing}

2.2.7. Information on how the GM plant differs from the recipient plant in terms of: reproduction, dissemination, and survivability

\subsubsection{Application scope: it is needed to define what is the target of the} genetic modification

(a) Solving agronomic problems: aiming to decrease agrotoxic applications, pest resistance, weeds, environmental stress (salinity, drought); (b) agricultural management practices: herbicide resistance; (c) improvement of product quality: processing or nutritional improvement; and (d) pharmacological intention.

\subsection{Genetically modified plants assessment}

The assessment is performed through the analysis of indicators which are arranged according to their area criteria (coded with letters) in two ways: general or technical such as: environmental (A), institutional (B) capacity development (C), economic (D), social (E) (General Assess); genetic features (F), GM plant features (G), gene flow $(\mathrm{H})$, food/feed field $(\mathrm{I})$, introduction of the GMP $(\mathrm{J})$, unexpected occurrences (K) and specific indicators field (L) (Technical Assess). The novelty is the possibility to add specific parameters to the GMP under assessment. In this case by case analysis the factors of moderation and the indexes are parameterized to run helpful assessment. Three tools support the Proposed Impact Assessment Method for Genetically Modified Plant 'AS-GMP Method': (a) worksheets to compile the Prospective Range, through the Significance Index; (b) indicator worksheets to compile an Impact Level Performance defined by the Magnitude Index. Finally the combination of both

Table 5

Risk perception of the GMP or its application.

\begin{tabular}{lc}
\hline Risk perception of the GMP or its application & Weight \\
\hline Risk perception null (no kind of sues perpetrated & 0 \\
against similar technology) & -2 \\
Unfavorable risk perception & +2 \\
Benefit perception tested by groups of interest & \\
associated with technology use & \\
\hline
\end{tabular}


Table 6

Worksheet of indicators to compile an Impact Level Performance: the Magnitude Index ${ }_{\mathrm{Gen}}$ - Environmental field (A).

\begin{tabular}{|c|c|c|c|}
\hline Weight & Indicator/moderation factor & $\begin{array}{l}\text { Data/information } \\
\text { for evaluation }\end{array}$ & Factor's weight range \\
\hline \multicolumn{4}{|c|}{ Environment field } \\
\hline \multicolumn{4}{|c|}{ Water resources, soil and air } \\
\hline 2 & Water quality (turbidity, OBD, etc ... due to innovation introduction) & & Gets worse $(-1) /$ maintains $(0) /$ gets better $(1)$ \\
\hline 2 & Heavy metal amount due to innovation introduction & & Increases $(-1) /$ maintains $(0) /$ decreases $(1)$ \\
\hline 2 & Chemical or organic residues (industrial sewer, waste, etc) & & Increases $(-1) /$ maintains $(0) /$ decreases $(1)$ \\
\hline 2 & Air pollutants emission in the air due to innovation introduction & & Increases $(-1) /$ maintains $(0) /$ decreases $(1)$ \\
\hline 2 & $\begin{array}{l}\text { Change on natural resources demand (comparative analysis of use and } \\
\text { consumption of water, soil, mineral) }\end{array}$ & & Increases $(-1) /$ maintains $(0) /$ decreases $(1)$ \\
\hline \multicolumn{4}{|c|}{ Biological resources: microorganism, flora and fauna } \\
\hline 2 & $\begin{array}{l}\text { Change on ecosystem balance (change on ecological level: } \\
\text { microorganisms, flora and fauna) }\end{array}$ & & $\begin{array}{l}\text { Affects individual }(-1) \text { /affects community } \\
(-2) \text { /does not affect any ecological level }(0)\end{array}$ \\
\hline 2 & $\begin{array}{l}\text { Occurrence of negative effects on plants, animals and human health } \\
\text { (occurrence of diseases, contamination and/or death) }\end{array}$ & & $\begin{array}{l}\text { Yes }(-1) / \\
\text { No }(0)\end{array}$ \\
\hline 2 & $\begin{array}{l}\text { Change on natural resources demand (comparative analysis of animal } \\
\text { and/or vegetal use and consumption) }\end{array}$ & & Increases $(-1) /$ maintains $(0) /$ decreases $(1)$ \\
\hline \multicolumn{4}{|c|}{ Environmental conservation } \\
\hline \multirow[t]{4}{*}{2} & aEnvironmental management or monitoring practice & & Creation (2) \\
\hline & Comparative analysis with conventional methods. The management used & & Improvement (1) \\
\hline & prior to the innovation was effective for environmental conservation matters. & & Does not interfere $(0)$ \\
\hline & & & Extinction $(-2)$ \\
\hline \multicolumn{4}{|c|}{ Environmental recovery } \\
\hline 3 & ${ }^{\text {a}}$ Reduction of level of solid, chemical and biological pollutants & & Yes $(1) /$ no $(0)$ \\
\hline \multirow[t]{2}{*}{3} & aBiodegradation Mechanisms & & Creation $(2) /$ \\
\hline & The innovation is a biodegradation mechanism that recovers a degraded area. & & $\begin{array}{l}\text { Improvement (1)/ } \\
\text { Does not apply (0) }\end{array}$ \\
\hline \multirow[t]{2}{*}{3} & ${ }^{\mathrm{a}}$ Gives stability to a threatened ecosystem & & Yes $(1) /$ \\
\hline & Comparison with the ecosystem prior to innovation introduction & & No $(0)$ \\
\hline
\end{tabular}

a Potential impact (ex-ante): indicators used for ex-ante technology assessment.

Indexes (Significance and Magnitude) designs the (c) Matrix of Impact that is created by the General Impact Value.

\subsubsection{Worksheets to compile Prospective Range: the Significance Index ${ }_{G e n}-$ General Assessment}

The first tool identifies a prospective analysis of the objective related to the use of a specific biotechnology. In this phase of assessment the following moderation factors are considered: spatial range, reach and influence. This first part of the assessment may be used in ex-post assessment as well as in ex-ante assessment, either by an evaluator who is going to decide about a GMP application or by funding agencies/ investors which are going to choose among biotechnology projects when deciding the destination of financial resources.

These moderation factors are showed in a worksheet that gives values to the importance and significance of the factor in terms of the Extent of its use - local, regional, national and international - and the direct or indirect Scope of their application (environment, human health, product or process quality, social, economic, political and legal). The analysis of these

Table 7

Worksheet of indicators to compile an Impact Level Performance: the Magnitude Index ${ }_{G e n}$ - Institutional development field (B).

\begin{tabular}{|c|c|c|c|c|}
\hline Weight & Indicator/moderation factor & $\begin{array}{l}\text { Data/information } \\
\text { for evaluation }\end{array}$ & Factor's weight range & Correction factor \\
\hline \multicolumn{5}{|c|}{ Institutional development field } \\
\hline \multicolumn{5}{|c|}{ Normalization of partnerships } \\
\hline 2 & 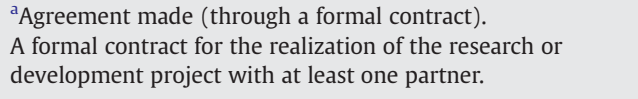 & & $\begin{array}{l}\text { Formal contract }(2) / \text { protocol } \\
\text { without legal value or a letter of } \\
\text { intent }(1) / \text { does not have }(0)\end{array}$ & \\
\hline \multicolumn{5}{|c|}{ Financial assistance } \\
\hline 2 & $\begin{array}{l}{ }^{\mathrm{a}} \text { Financial assistance ways } \\
\text { (high-risk fund, angel investor...). }\end{array}$ & & $\begin{array}{l}\text { Has financial assistance }(1) / \text { does } \\
\text { not have }(0)\end{array}$ & \\
\hline \multicolumn{5}{|c|}{ Partnerships } \\
\hline 2 & $\begin{array}{l}\text { a Number of partners. Total number of partners } \\
\text { (public, private, political instances, NGOs, civil organizations. }\end{array}$ & & $\begin{array}{l}\text { Note of the number of } \\
\text { partnerships }(+1)\end{array}$ & $\begin{array}{l}\text { Partner focus: social projects }(+1) / \\
\text { Environmental environmental projects }(+1)\end{array}$ \\
\hline \multicolumn{5}{|c|}{ Quality system implemented } \\
\hline 2 & $\begin{array}{l}\text { aISO or another quality certificate. } \\
\text { If a partner has one or more quality certificates } \\
\text { (ISO 9001; 14000; or another one). }\end{array}$ & & $\begin{array}{l}\text { Give }(+1) \text { one point for each } \\
\text { quality system implemented } \\
\text { (in each partner institution) }\end{array}$ & \\
\hline 2 & Normative service. Ex-ante ${ }^{a}$ : Yes. & & Yes $(1) /$ no $(0)$ & \\
\hline
\end{tabular}

\footnotetext{
a Potential impact (ex-ante): indicators used for ex-ante technology assessment.
} 
Table 8

Worksheet of indicators to compile an Impact Level Performance: the Magnitude Index ${ }_{\mathrm{Gen}}$ - Capacity field (C).

\begin{tabular}{|c|c|c|c|c|c|c|}
\hline Weight & Indicator/moderation factor & $\begin{array}{l}\text { Data/information } \\
\text { for evaluation }\end{array}$ & Factor's weight range & \multicolumn{3}{|l|}{ Correction factor } \\
\hline \multicolumn{7}{|c|}{ Capacity field } \\
\hline \multicolumn{7}{|c|}{ Formation of human resources } \\
\hline 2 & 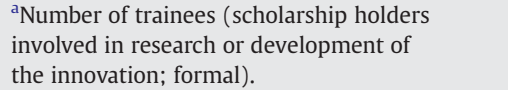 & & $\begin{array}{l}\text { Give }(+1) \text { one point for each } \\
\text { trainee (in each partner institution). }\end{array}$ & & & \\
\hline 2 & $\begin{array}{l}\text { aNumber of graduate students Masters, } \\
\text { PhD, Post-Doc, MBA, involved in the } \\
\text { research or development of the } \\
\text { innovation. }\end{array}$ & & $\begin{array}{l}\text { Give }(+1) \text { one point for each } \\
\text { graduate student involved } \\
\text { (in each partner institution). }\end{array}$ & & & \\
\hline \multicolumn{7}{|c|}{ Trainings } \\
\hline 2 & $\begin{array}{l}\text { aTechnical trainings (trainings directly related to } \\
\text { R\&D activities to capacitate the involved team) }\end{array}$ & & $\begin{array}{l}\text { Give }(+1) \text { one point to each } \\
\text { training carried out for the } \\
\text { development of the innovation. }\end{array}$ & \multirow{2}{*}{\multicolumn{3}{|c|}{$\begin{array}{l}\text { Number of participants: Up to } 10 \% \\
\text { of the employees of the organization } \\
(+1) \text { /over } 10 \%(+2) \\
\text { Number of participants: Up to } 10 \% \text { of } \\
\text { the employees of the organization } \\
(+1) / \text { over } 10 \%(+2)\end{array}$}} \\
\hline 2 & $\begin{array}{l}{ }^{a} \text { Lectures or trainings related to quality systems } \\
\text { (project team members and collaborators) }\end{array}$ & & $\begin{array}{l}\text { Give }(+1) \text { one point to each } \\
\text { training carried out for the } \\
\text { development of the innovation. }\end{array}$ & & & \\
\hline \multicolumn{7}{|c|}{ Scientific production } \\
\hline 2 & $\begin{array}{l}\text { Defended MSc dissertations } \\
\text { associated to the innovation. }\end{array}$ & & $\begin{array}{l}\text { Give one point for each finished } \\
\text { dissertation related to the } \\
\text { innovation }(+1)\end{array}$ & & & \\
\hline 2 & $\begin{array}{l}\text { Defended PhD theses associated } \\
\text { to the innovation. }\end{array}$ & & $\begin{array}{l}\text { Give one point for each finished thesis } \\
\text { related to the innovation }(+1) \text {. }\end{array}$ & & & \\
\hline 2 & $\begin{array}{l}\text { Scientific papers published in national } \\
\text { or international journals of the } \\
\text { innovation sector. }\end{array}$ & & $\begin{array}{l}\text { Give one point for each published } \\
\text { paper related to the innovation }(+1)\end{array}$ & $\begin{array}{l}\text { Factor } 1 \\
\text { Another sector }(+1) \text { / } \\
\text { same sector }(+2)\end{array}$ & $\begin{array}{l}\text { Factor } 2 \\
\text { National }(+1) / \\
\text { Intern. }(+2)\end{array}$ & \\
\hline 2 & $\begin{array}{l}\text { Number of abstracts in proceedings and } \\
\text { presentations in conferences. }\end{array}$ & & $\begin{array}{l}\text { Give }(+1) \text { one point for } \\
\text { each presented work related } \\
\text { to the innovation. }\end{array}$ & $\begin{array}{l}\text { Factor } 1 \\
\text { Another sector }(+1) / \\
\text { same }(+2)\end{array}$ & $\begin{array}{l}\text { Factor } 2 \\
\text { Number of partic. } \\
\text { up to } 250(+1) \\
\text { over }(+2)\end{array}$ & $\begin{array}{l}\text { Factor } 2 \\
\text { National }(+1) \\
\text { Intern. }(+2)\end{array}$ \\
\hline
\end{tabular}

a Potential impact (ex-ante): indicators used for ex-ante technology assessment.

Table 9

Worksheet of indicators to compile an Impact Level Performance: the Magnitude Index $\mathrm{Gen}_{-}$Economic Field (D).

\begin{tabular}{|c|c|c|c|c|}
\hline Weight & Indicator/moderation factor & $\begin{array}{l}\text { Data/information } \\
\text { for evaluation }\end{array}$ & Factor's weight range & Correction factor \\
\hline \multicolumn{5}{|c|}{ Economic Field } \\
\hline \multirow[t]{2}{*}{3} & \multirow{2}{*}{$\begin{array}{l}\text { Financial return (cost reduction - work force reduction, } \\
\text { economy of raw material, energy etc.) }\end{array}$} & & Occurs (1) & Factor \\
\hline & & & Does not occur $(0)$ & $\begin{array}{l}\text { Up to three years }(+2) / 3 \text { to } \\
5 \text { years }(+1) / \text { over } 5 \text { years }(0)\end{array}$ \\
\hline \multirow[t]{2}{*}{2} & \multirow{2}{*}{$\begin{array}{l}\text { aQualitative return (process improvement, } \\
\text { normative service, knowledge multiplication etc.) }\end{array}$} & & Occurs (1) & \\
\hline & & & Does not occur $(0)$ & \\
\hline \multirow[t]{2}{*}{3} & \multirow{2}{*}{$\begin{array}{l}\text { aForeign currency increased } \\
\text { (perspective of international trade relationships) }\end{array}$} & & Occurs (1) & \\
\hline & & & Does not occur $(0)$ & \\
\hline 2 & ${ }^{\text {aPayment/reception of royalties }}$ & & $\begin{array}{l}\text { Payment in the acquisition of } \\
\text { technology. National }(-1) \text {. } \\
\text { International }(-2) \text {. } \\
\text { Reception (2) }\end{array}$ & \\
\hline \multirow[t]{4}{*}{2} & \multirow{4}{*}{$\begin{array}{l}{ }^{a} \text { Control of productive chain (if innovation components come } \\
\text { from other links of the productive chain) }\end{array}$} & & High control (2) & \\
\hline & & & Medium (1) & \\
\hline & & & Low $(0)$ & \\
\hline & & & None $(-1)$ & \\
\hline \multirow[t]{3}{*}{2} & \multirow[t]{3}{*}{${ }^{a}$ Market where the innovation will be inserted. } & & Monopoly $(-2)$ & \\
\hline & & & Oligopoly $(-1)$ & \\
\hline & & & Competitive (0) & \\
\hline 2 & ${ }^{a}$ Market perspective (demand size) & & High (2)/medium (1)/low (0) & \\
\hline \multirow[t]{2}{*}{2} & aproduct life cycle (time during which the product & & Long (1) & \\
\hline & will stay on the market) & & Short(0) & \\
\hline \multirow[t]{2}{*}{2} & aEntry barriers (difficulties to enter the market) & & High $(-1)$ & \\
\hline & & & Low (1) & \\
\hline \multirow[t]{2}{*}{3} & ${ }^{a}$ Value added. & & High (1) & \\
\hline & High technology, high knowledge level and $R \& D$ investment results & & Low $(0)$ & \\
\hline \multirow[t]{2}{*}{3} & ${ }^{\mathrm{a}}$ The innovation may be commercialized & & Yes $(+1)$ & \\
\hline & If the final object of the innovation has potential to be commercialized. & & No $(0)$ & \\
\hline
\end{tabular}

\footnotetext{
a Potential impact (ex-ante): indicators used for ex-ante technology assessment.
} 
Table 10

Worksheet of indicators to compile an Impact Level Performance: the Magnitude Index ${ }_{\text {Gen }}-$ Social Field (E).

\begin{tabular}{|c|c|c|c|c|c|}
\hline Weight & Indicator/moderation factor & $\begin{array}{l}\text { Data/information } \\
\text { for evaluation }\end{array}$ & Factor's weight range & \multicolumn{2}{|l|}{ Correction factor } \\
\hline \multicolumn{6}{|c|}{$\begin{array}{l}\text { Social field } \\
\text { Work relations }\end{array}$} \\
\hline 3 & $\begin{array}{l}\text { Influence on work conditions } \\
\text { (worker health and safety) }\end{array}$ & & $\begin{array}{l}\text { Improves }(1) \text { keeps }(0) \\
\text { worsens }(-2)\end{array}$ & & \\
\hline 3 & Reduction of jobs & & $\begin{array}{l}\text { Demission }(-1) \\
\text { Fair reallocation }(0)\end{array}$ & & \\
\hline 3 & Creation of jobs. (direct/indirect) & & $\begin{array}{l}\text { Occurs (2) } \\
\text { Does not occur }(0)\end{array}$ & $\begin{array}{l}\text { Factor } 1 \\
\text { Temporary }(+1) \\
\text { Permanent }(+2)\end{array}$ & $\begin{array}{l}\text { Factor } 2 \\
\text { Direct }(+2) \\
\text { Indirect }(+1)\end{array}$ \\
\hline \multicolumn{6}{|c|}{ Social reach } \\
\hline 2 & $\begin{array}{l}\text { aSocial class that benefits from the } \\
\text { innovation }\end{array}$ & & $\begin{array}{l}\text { Occurs }(1) \\
\text { Does not occur }(-1)\end{array}$ & \multicolumn{2}{|c|}{$\begin{array}{l}\text { Class A }(+1) / \text { class B }(+2) / \text { class C }(+3) \\
\text { Class D }(+4) / \text { class E }(+5)\end{array}$} \\
\hline \multicolumn{6}{|c|}{ Science popularization } \\
\hline 2 & $\begin{array}{l}\text { Number of lectures and courses } \\
\text { given, number of participants and } \\
\text { kind of audience. }\end{array}$ & & $\begin{array}{l}\text { Give one point }(+1) \text { to each } \\
\text { presented lecture related to } \\
\text { the innovation. }\end{array}$ & $\begin{array}{l}\text { Factor } 1 \\
\text { National }(+1) \\
\text { Intern. }(+2)\end{array}$ & $\begin{array}{l}\text { Factor } 2 \\
\text { Number of participants. }- \text { up } \\
\text { to } 50(+1) \text { /over } 50(+2)\end{array}$ \\
\hline 2 & Articles in newspapers/media & & $\begin{array}{l}\text { Give one point to each article } \\
\text { related to the innovation. }\end{array}$ & $\begin{array}{l}\text { Factor } \\
\text { National }(+1) / \text { Intern. }(+2)\end{array}$ & \\
\hline
\end{tabular}

a Potential impact (ex-ante): indicators used for ex-ante technology assessment.

moderation factors allows the generation of the Significance Index ${ }_{G e n}$ (Table 1). It is given a range of values to each moderation factor of innovation. Each weight given to the moderation factors will be considered for the generation of the Significance Index ${ }_{G e n}$, according to the formula below:

$\Sigma\left(\right.$ Scope $_{\mathrm{a}, \mathrm{g}} \times$ Influence $\left._{\mathrm{a}, \mathrm{g}}\right)=$ Biotechnology Range

Biotechnology Range $\times$ Extent $=$ Significance Index $_{\text {Gen }}$.

\subsubsection{Worksheets to compile the Scenario for the GMP Introduction: the} Significance Index $x_{\text {tech }}$ - Technical Assessment

The scenario of the GMP is composed of safety information that has been already searched in a laboratory essay or based in the literature (Table 2): i) data/tests of the genetic insertion safety; ii) tests of stability of the insertion, iii) tests of stability of the new feature, and iv) evaluation of agronomic applications, tests of innocuity of the new product (aimed at a pharmaceutical or cosmetic), or tests of feed safety (substantial equivalence). In the item iv) just one characteristic must be filled. Each weight given to moderation factors will be considered for the generation

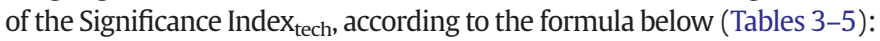

$$
\begin{aligned}
& \Sigma\left(\text { Occurrence }_{\mathrm{i}, \mathrm{iv}} \times \text { Developmental stage }_{\mathrm{i}, \mathrm{iv}} \times{\text { Result } \left.\text { obtained }_{\mathrm{i}, \mathrm{iv}}\right)}^{\quad=\text { Safety tests }(\text { Table } 2)}\right.
\end{aligned}
$$

$$
\text { Safety test }+ \text { Plantation site }+ \text { Reproduction sp }+ \text { Risk perception }
$$$$
=\text { Significance Index }_{\text {tech }} \text {. }
$$

\subsubsection{Indicators worksheets to compile an Impact Level Performance: the} Magnitude Index

The second tool consists on preformatted worksheets (Tables 6-17) that organize the parameters or indicators according to the focus of the

\begin{tabular}{|c|c|c|c|}
\hline Weight & Indicator/moderation factor & $\begin{array}{l}\text { Data/information } \\
\text { for evaluation }\end{array}$ & Factor's weight range \\
\hline \multicolumn{4}{|c|}{ Genetic Insert Features Field } \\
\hline \multicolumn{4}{|c|}{ Genetic insert } \\
\hline 2 & Dissemination of diseases, development of antibiotic resistance. & & Yes $(-1) /$ no $(0)$ \\
\hline 2 & Presence of unwanted, regulatory or marker nucleotide sequences that presents some risk & & Yes $(-1) /$ no $(0)$ \\
\hline 2 & $\begin{array}{l}\text { Known ORFs - open reading frames (if potential chimeric ORFs are identified bioinformatic analyses } \\
\text { should be conducted to investigate the possibility for similarities with known toxins or allergens). }\end{array}$ & & Yes $(-1) /$ no $(0)$ \\
\hline \multicolumn{4}{|c|}{ Appearance of other negative characteristics } \\
\hline 2 & Stability of the insert & & Yes $(+1) /$ no $(-1)$ \\
\hline 2 & Phenotypic and compositional differences, pest and disease reactions & & Improves $(1) /$ maintains $(0) /$ worsens $(-1)$ \\
\hline \multicolumn{4}{|c|}{ Expressed protein } \\
\hline 2 & Occurrence of negative effects on plant, human or animal health & & Occurs $(-1) /$ does not occur $(0)$ \\
\hline 2 & Protein specificity & & Yes $(1) /$ no $(-1)$ \\
\hline 2 & Homology with known allergenic or toxic proteins & & Yes $(-1) /$ no $(1)$ \\
\hline 2 & Protein stability & & Yes $(1) /$ no $(-1)$ \\
\hline \multirow[t]{2}{*}{2} & Transcriptional and/or translational data (may be required to investigate & & Presence $(-1)$ \\
\hline & if novel proteins are synthesized) & & Absence $(+1)$ \\
\hline \multirow[t]{2}{*}{2} & Mitochondria or chloroplasts flanks the insert (as can occur with biolistic & & Presence $(-1)$ \\
\hline & delivery methods) & & Absence $(+1)$ \\
\hline \multicolumn{4}{|c|}{ Effects on non-target organisms } \\
\hline 3 & Occurrence of negative effects on non-target organisms & & Occurs $(-1) /$ does not occur $(0)$ \\
\hline 3 & Protein toxicity or allergenicity for non-target organisms & & Occurs $(-1) /$ does not occur $(0)$ \\
\hline
\end{tabular}

Table 11

Worksheet of indicators to compile an Impact Level Performance: the Magnitude Index ${ }_{\text {Tech }}$ - Genetic Insert Features Field (F). 
Table 12

Worksheet of indicators to compile an Impact Level Performance: the Magnitude Index Tech $_{-}$Features of GM Plant Field (G).

Weight Indicator/moderation factor Data/information weight range
for evaluation

\section{Features of GM Plant Field}

Generation of plants with weedy aspects

$2 \quad$ Alteration of reproductive, competitive or adaptive ability.

2 Recipient plant with weedy aspects.

Yes $(-1) /$ no $(0)$

Yes $(-1) /$ no $(0)$

Outbreak of additional attributes

$2 \quad$ Gene specificity.

2 Biological features that affect fitness and environmental sensitivity

Yes $(1) /$ no $(0)$

Yes $(-1) /$ no $(0)$

(e.g. multiplication, dormancy, survivability, dispersal).

Information on the expression of the insert

2 Information on developmental expression of the insert during the life cycle of the plant

2 Changing in biology and agronomic traits, including common breeding parameters

(e.g. plant morphology, flowering time, duration of pollen viability).

2 Expression of potential fusion proteins (should be investigated by bioinformatic analysis)

$2 \quad$ Changes in susceptibility to important pests and diseases.

Mechanism of interaction between the GM plant and target organisms

2 Expression and mode of action is specific to target organism of any new traits present in the modified plant.

Improves (1)/maintains (0)/worsens $(-1)$ Yes $(-1) /$ no $(0)$

Yes $(-1) /$ no $(0)$

Increase $(-1)$ /decrease $(1) /$ does not alter $(0)$

Specific (1)/non-specific $(-1) /$ there is no target organism in the event $(0)$

Interactions between the GM plant and its biotic environment

$2 \quad$ Effects on the numbers and diversity of relevant populations of species in the receiving environment (plant, animal, microbe);

2 Altered susceptibility to pests and pathogens facilitating the dissemination of infectious diseases and/or creating new reservoirs or vectors

Affects individual $(-1)$ /affects community $(-2)$ /does not affect other organism (0)

Increases susceptibility $(-1)$

Decreases susceptibility (1)

Does not alter susceptibility $(0)$

Improves treatment $(1)$ /worsens $(-1)$ /does not affect $(0)$

Yes $(1) /$ no $(0)$

2 Effects on beneficial plant-microbial associations and biogeochemistry

(biogeochemical cycles), particularly on microbial-mediated carbon and nitrogen

recycling through changes in soil decomposition of organic material.

Potential interactions with the abiotic environment

$2 \quad$ Alteration of climatic conditions (e.g. altered production of greenhouse gases)

Altered sensitivity to, or tolerance of climatic conditions (e.g. cold, heat, humidity).

Improves (1)/maintains (0)/worsens $(-1)$ Improves $(1) /$ maintains $(0)$ /worsens $(-1)$ Altered sensitivity to, or tolerance of abiotic fractions of soil (e.g. salinity, mineral nutrients, mineral toxins).

2 Altered sensitivity to, or tolerance of gases (e.g. $\mathrm{CO}_{2}$, oxygen, $\mathrm{NH}_{3}$ ).
2 Alteration of mineralization (e.g. root exudates changing the soil $\mathrm{pH}$ ).

2 Altered sensitivity to, or tolerance of gases (e.g. $\mathrm{CO}_{2}$, oxygen, $\mathrm{NH}_{3}$ ).
2 Alteration of mineralization (e.g. root exudates changing the soil $\mathrm{pH}$ ).

Improves (1)/maintains $(0)$ /worsens $(-1)$

Improves (1)/maintains (0)/worsens $(-1)$

Improves $(1) /$ maintains $(0)$ /worsens $(-1)$

Persistence and invasiveness

2 GM plant becomes more persistent or invasive than the non-GM counterpart.

Yes $(-1) /$ no $(0)$

field and enable users to fill in values related to the level of importance or magnitude of the parameters.

The goal of this method creation is to consider the indicators assessment within every possible field, without privileging any para- meter. In this way, AS-GMP Method foresees the regulation of weights, but does not prioritize fields.

In case of an ex-post assessment, the indicators worksheet must be fully evaluated, whereas in case of an assessment ex-ante the

Table 13

Worksheet of indicators to compile an Impact Level Performance: the Magnitude Index ${ }_{\text {Tech }}-$ Gene Flow Field $(\mathrm{H})$.

\begin{tabular}{|c|c|c|c|}
\hline Weight & Indicator/moderation factor & $\begin{array}{l}\text { Data/information } \\
\text { for evaluation }\end{array}$ & $\begin{array}{l}\text { Factor's weight } \\
\text { range }\end{array}$ \\
\hline \multicolumn{4}{|c|}{ Gene Flow Field } \\
\hline 3 & $\begin{array}{l}\text { Unexpected dissemination due to outcrossing with } \\
\text { conventional genotype }\end{array}$ & & Yes $(-1) /$ no $(0)$ \\
\hline \multicolumn{4}{|c|}{ Alteration in the population distribution of weed or native species } \\
\hline 3 & Outcrossing with weed or wild species. & & Yes $(-1) /$ no $(0)$ \\
\hline \multicolumn{4}{|c|}{ Alteration in other non-target organisms } \\
\hline 3 & Gene flow to non-target organisms (horizontal flow) & & Yes $(-1) /$ no $(0)$ \\
\hline
\end{tabular}


Table 14

Worksheet of indicators to compile an Impact Level Performance: the Magnitude Index ${ }_{\text {Tech }}$ - Food/feed Field (I).

\begin{tabular}{|c|c|c|c|}
\hline Weight & Indicator/moderation factor & $\begin{array}{l}\text { Data/information } \\
\text { for evaluation }\end{array}$ & Factor's weight range \\
\hline \multicolumn{4}{|c|}{ Food/feed Field } \\
\hline \multicolumn{4}{|c|}{ Effect of processing } \\
\hline 2 & $\begin{array}{l}\text { Processing and/or preserving needs } \\
\text { (compared with its non-GM counterpart) }\end{array}$ & & Increases needs $(-1) /$ decreases needs $(1) /$ does not alter $(0)$ \\
\hline 2 & $\begin{array}{l}\text { Threat to agricultural management practices. } \\
\text { Comparative analysis with conventional methods }\end{array}$ & & Increases needs $(-1) /$ decreases needs $(1) /$ does not alter $(0)$ \\
\hline \multicolumn{4}{|c|}{ Nutritional assessment } \\
\hline 2 & The dietary role of the product and the expected level of use. & & Yes $(1) /$ no $(0)$ \\
\hline 3 & Nutrient composition - alteration after the genetic insertion. & & Improves (1)/maintains $(0) /$ worsens $(-1)$ \\
\hline 3 & Biological efficacy of nutrient components in the food & & Improves (1)/maintains $(0)$ /worsens $(-1)$ \\
\hline 2 & Assessment of dietary intake and nutritional impact. & & Improves (1)/maintains (0)/worsens $(-1)$ \\
\hline \multicolumn{4}{|c|}{ Commercial management regimes } \\
\hline 2 & $\begin{array}{l}\text { Changes on applications of plant protection products } \\
\text { (pesticides and/or biocontrol agents), for the GM plant where } \\
\text { these are different from the equivalent non-GM plant. }\end{array}$ & & Increases needs $(-1) /$ decreases needs $(1) /$ does not alter $(0)$ \\
\hline 2 & $\begin{array}{l}\text { Changes on rotations and other plant management measures } \\
\text { for the GM plant where these are different from the equivalent non-GM plant. }\end{array}$ & & Improves (1)/maintains $(0)$ /worsens $(-1)$ \\
\hline
\end{tabular}

biotechnology appliance, only some potential indicators (marked with a star) must be analyzed.

Each weight given to indicators or moderation factors will be taken into account when generating the Magnitude Index, according to the formula below:

$$
\begin{array}{r}
\text { Indicator Weight }_{\mathrm{a}, \mathrm{l}} \times \text { Weight range value }_{\mathrm{a}, \mathrm{l}}+\Sigma\left(\text { Correction Factors }_{\mathrm{a}, \mathrm{l}}\right) \\
=\text { Total Weight of Indicators from Field } \mathrm{A}=\text { Total weight of Field } \mathrm{A}
\end{array}
$$

\section{$\Sigma$ (Total Weight of Field A, B, C, D, E) / Number of Fields Analyzed $=$ Magnitude Index (General Impact Index)}

\section{$\Sigma$ (Total Weight of Field F, G, H, I, J, K, L) / Number of Fields Analyzed $=$ Magnitude Index $_{\text {Tech }}$ (Technological Impact Index).}

\subsection{Fields for indicator description, indicator weight, factors of moderation and criteria of assessment}

On the worksheet the parameter or indicator under assessment is grouped within its field according to its criterion or characteristic. These items are predetermined on the worksheet in order to allow an accurate evaluation of related impacts.

These summarized data on the indicators worksheet were identified and compiled with the contribution of experts from several areas of the assessment approach. This counsel was carried out through personal interviews, with the purposes of: firstly to identify and consolidate the necessary indicators and thereafter to make adjustments on indicators' weights and weight ranges of each moderation and correction factors, when necessary. Some tests were accomplished for adjustments not only on used parameters but also on the functionality of the support Software for the system application.

To each indicator presented on Tables 6-17 the method gives a weight, which varies from 1 to 3 . This variation in weight is done as follows: indicators that show a higher weight are the ones with potentialized impact. For example, in the case of Environmental Field the indicators of environment recovery have weight 3 , since according to this item a certain environment may be recovered potentializing its future use for conservation or preservation. On the same way, it is given the maximum value (3) to the field 'unexpected events' since it brings the possibility of adverse or undesirable effects. On the other hand, indicators added by users have weight 1 , so that the final result does not suffer great distortions.

In spite of creating a hierarchy within each field, this will not be used for the decision-making but for a scenario generation and so the general panorama of the GMP environment. In this way, the fields' weights are the same, since they are considered equally important. In other words, the biotechnology assessment should contemplate the use of AS-GMP Method in each of its fields. In case an indicator is not significant for the GMP under analysis it should be ignored, in the same way more specific new indicators for the evaluation can be added to the field "Specific indicators".

Table 15

\begin{tabular}{|c|c|c|c|}
\hline Weight & Indicator/moderation factor & Data/information for evaluation & Factor's weight range \\
\hline \multicolumn{4}{|c|}{ Introduction of the GMP Field } \\
\hline \multicolumn{4}{|c|}{ Technological advancement } \\
\hline 2 & Threat to the agricultural management practices & & Improves ( 1$) /$ maintains (0)/worsens $(-1)$ \\
\hline 2 & Comparative analysis with conventional methods & & Improves ( 1$)$ /maintains $(0) /$ worsens $(-1)$ \\
\hline \multicolumn{4}{|c|}{ Decreases in the efficacy of the technology } \\
\hline 3 & Probability to generate mutations in the target organisms & & Increases $(-1) /$ decreases $(1) /$ does not alter $(0)$ \\
\hline \multicolumn{4}{|c|}{ Increasing the demand for natural resources } \\
\hline 2 & Comparative analysis regarding soil and water usage and quality & & Increases needs $(-1) /$ decreases needs $(1) /$ does not alter $(0)$ \\
\hline
\end{tabular}

Worksheet of indicators to compile an Impact Level Performance: the Magnitude Index ${ }_{\text {Tech }}$ - GMP introduction field (J). 
Table 16

Worksheet of indicators to compile an Impact Level Performance: the Magnitude Index $\mathrm{Tech}_{\mathrm{T}}$ - Unexpected occurrences field (K).

\begin{tabular}{|c|c|c|c|}
\hline Weight & Indicator/moderation factor & $\begin{array}{l}\text { Data/information } \\
\text { for evaluation }\end{array}$ & Factor's weight range \\
\hline \multicolumn{4}{|c|}{ Unexpected occurrences (accidents) } \\
\hline 2 & Adverse environmental effect & & Occurs $(-1) /$ does not occur $(0)$ \\
\hline 2 & Possibility of improper use of the GMP & & Occurs $(-1) /$ does not occur $(0)$ \\
\hline 2 & Damage to human, animal or plant health & & Occurs $(-1) /$ does not occur $(0)$ \\
\hline 2 & Lawsuit against the GMP & & Occurs $(-1) /$ does not occur $(0)$ \\
\hline 2 & Risk of adopting the technology related to the characteristic of the GMP. & & High $(-2)$ Medium medium $(-1)$ low $(0)$ \\
\hline 2 & $\begin{array}{l}\text { Information on any toxic, allergenic or other harmful effects on human } \\
\text { or animal health arising from the GM food/feed }\end{array}$ & & Occurs $(-1) /$ does not occur $(0)$ \\
\hline \multicolumn{4}{|c|}{ GMO dissemination due to extreme climatic events } \\
\hline 3 & Geographic connection to sensitive areas in the region & & Yes $(-1) /$ no $(0)$ \\
\hline 3 & $\begin{array}{l}\text { Site location - proximity of problematic areas (e.g., field trial located } \\
\text { in the property near a river). }\end{array}$ & & Yes $(-1) /$ no $(0)$ \\
\hline 3 & Period of occurrence of extreme climatic event & & Coincidence $(-1) /$ not coincidence $(0)$ \\
\hline \multicolumn{4}{|c|}{ GMO dissemination due to operational failure } \\
\hline 2 & Training of the team & & Necessary $(-1) /$ desirable $(1) /$ no need $(0)$ \\
\hline 2 & Final destination of the GMO & & Expensive $(-1) /$ cheap (1)/the same as non non-GM plant ( 0$)$ \\
\hline \multicolumn{4}{|c|}{ Dissemination due to theft of material } \\
\hline 3 & Physical safety of the property & & Yes $(1) /$ no $(-1)$ \\
\hline \multicolumn{4}{|c|}{ Toxicology } \\
\hline 3 & Toxicology tests in mammals. & & Positive result $(-1) /$ negative result $(1)$ \\
\hline 2 & Identified new constituents other than proteins which should be evaluated. & & Occurs $(-1) /$ does not occur $(0)$ \\
\hline \multicolumn{4}{|c|}{ Allergenicity } \\
\hline 3 & $\begin{array}{l}\text { Newly expressed protein has allergenic characteristics (e.g. Pepsin resistance test, } \\
\text { glycosylation site, IgE reaction). }\end{array}$ & & Yes $(-1) /$ no $(1)$ \\
\hline
\end{tabular}

Aiming to provide an accurate evaluation it is possible to ignore some fields or to perform just one kind of analysis either General or Technical because the results are presented separately. Otherwise it is suggested that the whole analysis bound is executed in order to have a complete assessment.

\subsection{Data/information for the evaluation field}

This central column is the field where the user describes all information related to the criterion of assessment. Literature searches or prospective data must be the source of scientific data, described to perform the ex-ante analysis or the scenario elucidation of the GMP. Experimental results from GMP application must be used as the assessment basis, that is, for weight allocation. These collected data must be inserted in the worksheet's central column in order to ensure the acuity and support of the achieved results.

These data will be shown on methodology results in electronic format (AS-GMP v1.0 Software) as a 'descriptive report'.

\subsection{Matrix of impact that is built by the General/Technical Impact Value}

The third tool provides a structure to observe the potential impact and the prospective scenario to introduce the GMP, in the ex-ante analysis. In the ex-post evaluation, that uses the Significance Index

\section{Table 17}

Worksheet of indicators to compile an Impact Level Performance: the Magnitude Index $_{\text {Tech }}$ - Specific indicators field (L)

\begin{tabular}{llll}
\hline Weight & $\begin{array}{l}\text { Indicator/moderation } \\
\text { factor }\end{array}$ & $\begin{array}{l}\text { Data/information } \\
\text { for evaluation }\end{array}$ & $\begin{array}{l}\text { Factor's weight } \\
\text { range }\end{array}$ \\
\hline 1 & $\begin{array}{l}\text { Specific indicators } \\
\text { Insert specific indicators } \\
\text { for your evaluation }\end{array}$ & $\begin{array}{l}\text { Insert justification or } \\
\text { explanation for the } \\
\text { indicators }\end{array}$ & $\begin{array}{l}\text { Give weights } \\
(-1 \text { to }+1)\end{array}$ \\
\hline
\end{tabular}

and all indicators to build the Magnitude Index. These both indexes are crossed to show the final result form: the analysis in a matrix format (Figs. 2 and 3).

After the identification of the technology scope, GMP characterization, impact assessment, and the significance analysis of related effects, the final step in this impact assessment process comes in reviewing the potential impact and establishing at which level impact management, through preventive or corrective actions, must be taken in order to allow an effective and safe use of the transgenic crop. This is performed by the Matrix of Assessment.

The Matrix (Figs. 2 and 3 ) is constructed with two axes, where the $x$ axis stands for the classes of the Index of Magnitude (indicators performance) and the $y$-axis stands for the classes of the Significance Index (Prospective Analysis/Scenario for the GMP Introduction). That is indicated in the matrix 'General/Technical Impact Value', which is the final result of all indicators of all fields. To complement the evaluation the results from the Magnitude and Significance Indexes for each field are plotted in the Matrix according to their position (points are plotted using letters that represent each field). The general value for the field performance is the result of the sums of all indicator values inside the field under evaluation. The illustration of this result of the field evaluation (plotting the letters like a code) allows formulating a list of recommendations with the objective of potentializing a positive impact of the GMP on each field. This measure favors the first proposition of the system: fields should be considered equally important, and thus corrective measures should be taken in order to mitigate distortions of impacts between them.

The level of performance of the technology under evaluation is classified as follows:

(1) Prospective assessment: unfavorable scenario to the GMP/GMP in early implementation stage (potential impact assessment) or with low perspective of success - GMP is not recommended.

(2) Prospective assessment: unfavorable scenario to the GMP/GMP with low performance - restrictions and corrective actions are recommended to the GMP. 


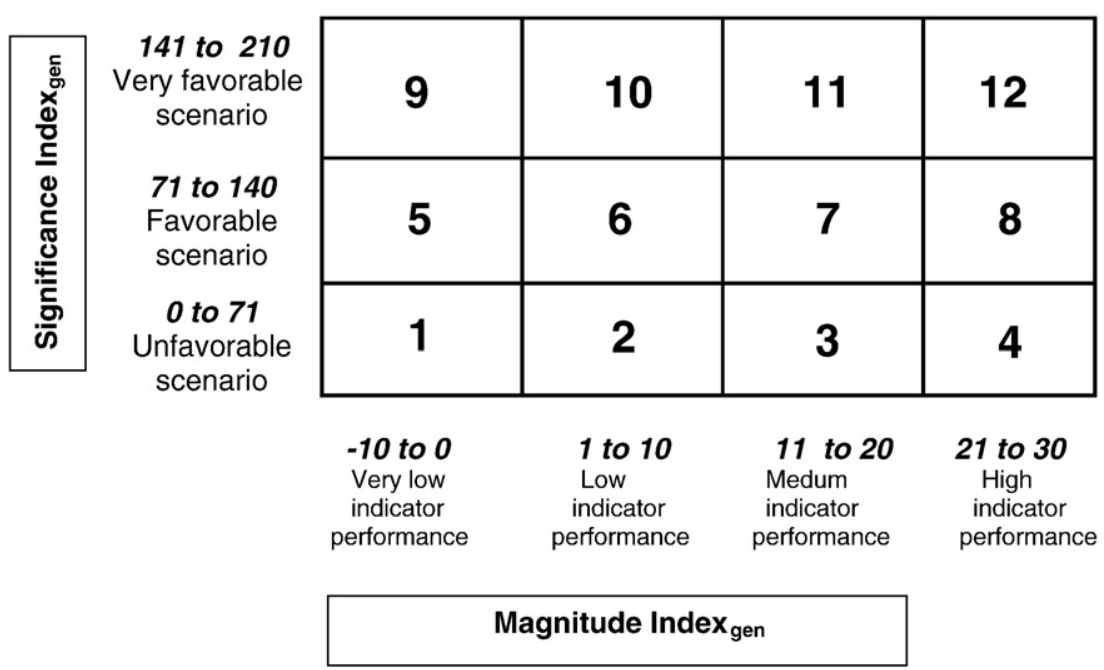

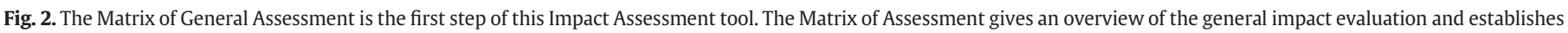

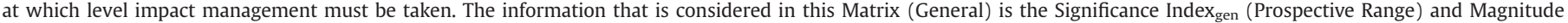
Index $_{\text {gen }}$ (General Impact Index). The $x$-axis represents the classes of the Magnitude Index and the $y$-axis represents the classes of the Significance Index.

(3) Prospective assessment: unfavorable scenario to the GMP/GMP with medium performance - monitoring with restrictions is recommended to the GMP.

(4) Prospective assessment: unfavorable scenario to the GMP/GMP with excellent performance - GMP is recommended.

(5) Prospective assessment: favorable scenario to the GMP/GMP in early implementation stage (potential impact assessment) or with low perspective of success - management with restrictions is required.

(6) Prospective assessment: favorable scenario to the GMP/GMP with low performance-corrective actions are recommended to the GMP.

(7) Prospective assessment: favorable scenario to the GMP/GMP with medium performance - monitoring or management is required to the GMP.

(8) Prospective assessment: favorable scenario to the GMP/GMP with excellent performance - GMP recommended.

(9) Prospective assessment: favorable scenario to the GMP - investments in the GMP are recommended/GMP low performance management required.
(10) Prospective assessment: scenario favorable scenario to the GMP investments are recommended/GMP low performance - management required.

(11) Prospective assessment: favorable scenario to the GMP investments are recommended/GMP medium performance monitoring required.

(12) Prospective assessment: favorable scenario to the GMP - investments are recommended-GMP excellent performance - GMP highly recommended.

\subsection{Digital format - introduction of the software AS-GMP (V. 1.0)}

The software AS-GMP v. 1.0 is an electronic format of the worksheets, created in Microsoft Visual Basic v. 6.0, which can be accessed at Embrapa Environment link: http://www.cnpma.embrapa. br/forms/as_gmp.php3 (GMP impact assessment file to download). To run the AS-GMP, just download the file to your PC and run it with a double click.

\begin{tabular}{|c|c|c|c|c|c|}
\hline \multirow{3}{*}{ 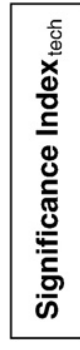 } & \multirow{3}{*}{$\begin{array}{c}11 \text { to } 20 \\
\text { Very favorable } \\
\text { scenario } \\
1 \text { to } 10 \\
\text { Favorable } \\
\text { scenario } \\
-20 \text { to } 0 \\
\text { Unfavorable }\end{array}$} & 9 & 10 & 11 & 12 \\
\hline & & 5 & 6 & 7 & 8 \\
\hline & & 1 & 2 & 3 & 4 \\
\hline & & $\begin{array}{l}-20 \text { to }-10 \\
\text { Very low } \\
\text { indicator } \\
\text { performance }\end{array}$ & $\begin{array}{l}-9 \text { to } 0 \\
\text { Low } \\
\text { indicator } \\
\text { performance }\end{array}$ & $\begin{array}{l}1 \text { to } 10 \\
\text { Medium } \\
\text { indicator } \\
\text { performance }\end{array}$ & $\begin{array}{l}11 \text { to } 20 \\
\text { High } \\
\text { indicator } \\
\text { performance }\end{array}$ \\
\hline
\end{tabular}

Magnitude Index $x_{\text {tech }}$

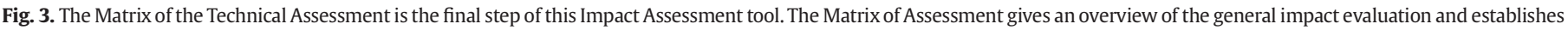

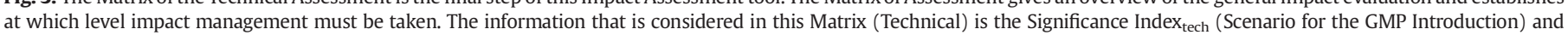
Magnitude Index $x_{\text {tech }}$ (Technical Impact Index). The $x$-axis represents the classes of the Magnitude Index and the $y$-axis represents the classes of the Significance Index. 


\section{Results}

By using this electronic format, it is possible to attribute values to the factors of moderation on the worksheets and to the results of the indexes (Significance and Magnitude). Those will be calculated and plotted in the Matrix of Impact automatically. These results can be presented in table or graph format and also in the description report.

\subsection{Compiled analysis}

The following step involves compiling and analyzing the results from the matrix and worksheets. Each field coded with a letter is plotted in the matrix aiming to require some measures according to the level of impact. These impact measures must consider all data described in the worksheet, such as the specificity of the GMP, the activity under analysis, release concerns and the scenario situation. Essentially, this compilation is the core structure for performing impact management.

Aiming to potentialize the positive impact of the GMP on different fields, the code that represents each field is plotted in the matrix's row compatible with its performance. The visual and graphic data presentation format facilitates to suggest corrective measures for its optimization or mitigation of negative impacts. Therefore, for a proper evaluation the user needs to formulate his/her list of recommendations specific to the GMP under analysis.

\section{Conclusions}

Prospective analysis must be carried out to predict the occurrence of negative impacts of some GM crops on the environment or on human health. Additionally, this analysis must forecast and optimize economic, capability, institutional or social success. These assessments allow us to define preventive measures to mitigate or avoid negative effects related to genetic insert features, GM plant features, gene flow, food/feed field, introduction of GMP, unexpected occurrences and specific indicators that could result in negative impacts.

This rapid appraisal allows us to define preventive measures to mitigate or avoid adverse effects or unexpected occurrences that could result from potential or identified hazards. Thus, it is possible to develop a transgenic crop with a high probability of success and safety.

The impact assessment proposed here includes parameters that allow an estimate of the performance level, which is based on the assignment of numeric values to several factors correlated with impact. It results in lower subjectivity and higher clearness in the analysis processes. Technologies with the same objectives can also be compared using the proposed system.

Considering the range of different genetical modifications to be evaluated and the performance behaviors and safety concerns that must be addressed on a case by case basis, the proposed system may not cover all aspects involved, though it presents a broad approach to impact assessment. Since there is always a likelihood of development of a new and better method that could be used in many situations, the user is encouraged to expand the possibilities of this tool by adding or deleting parameters according to the kind of technology addressed. On the other hand, investors and regulators must evaluate whether the chosen parameters are the best to define the potential impact of the GMP under analysis.

This strategy is very important to allow a less superficial method, since it is able to identify which parameters are more correlated with the transgenic crop. In addition, characterizing impact by measuring it with quantifiable tools demonstrates a quantitative method where subjectivity is drastically reduced. Compared to current processes, the proposed method represents a less subjective and clearer process for impact assessment.

\section{Acknowledgements}

The authors thank Dr. Denis Lima (Bayer S. A. - São Paulo-Brazil) and Mr. Hamilton Gustavo Palermo Hitzschky (computation consultant - Campinas-Brazil).

\section{References}

Conner AJ, Glare TR, Nap JP. The release of genetically modified crops into the environment Part II. Overview of ecological risk assessment. Plant J 2003;33:19-46.

De Greef W. GM Crops: The crushing cost of regulation. SeedQuest News Section; 2004 Available at: www.seedquest.com/News/releases/2004/april/8319.htm. 8 Jan 2009.

EFSA Journal - European Food Safety Authority. Guidance document of the scientific panel on genetically modified organisms for the risk assessment of genetically modified plants and derived food and feed. EFSA J 2006;99:1-100.

FAO - Food and Agriculture Organization of the United Nations. Secretariat of the International Plant Protection Convention. Pest risk analysis for quarantine pests, including analysis of environmental risks and living modified organisms, vol. 11 Publication; 2004. p. 37. Available at: http://www.fao.org/docrep/008/y5874e/ y5874e00.htm.

Jesus KRE, Lanna AC, Vieira FD, Abreu AL, Lima DU. A proposed Risk Assessment Method for Genetically Modified Plants. Appl Biosafety 2006;11(3):127-37.

Jesus-Hitzschky KRE. Impact Assessment System for Technological Innovation INOVA-tec System. J Technol Manag Innov 2007;2(2):67-82.

Kalaitzandonakes N, Alston JM, Bradford KJ. Compliance costs for regulatory approval of new biotech crops. Nat Biotechnol 2007;25:509-11.

NAS - National Academy of Sciences - Committee on Environmental Impacts Associated with Commercialization of Transgenic Plants, Board on Agriculture and Natural Resources, Division on Earth and Life Sciences, National Research Council. Environmental effects of transgenic plants: the scope and adequacy of regulation. Washington, DC: The National Academies Press; 2002.

OECD - Organization for Economic Co-operation and Development. Working group on harmonization of regulatory oversight in biotechnology. Environmental risk assessment of transgenic plants: a comparison of international pre-market data requirements; 2005. p. 17.

Zackiewicz, M. Trajetórias e Desafios da Avaliação em Ciência, Tecnologia e Inovação. Ph.D. Thesis, presented to Science and Technology Police Analysis Department, Institute of Geo-sciences, Unicamp, mimeo, 2005, 269 pp.

Katia Regina Evaristo de Jesus-Hitzschky ( $\mathrm{PhD}$ in Biotechnology, Researcher at Embrapa Environment, Jaguariuna, SP; Brazil). She got her Master's degree in Biotechnological Economy in 1999, then she started her PhD in Molecular Genetic of Microorganisms in the Biotechnology Program. She started working with biosafety in 2001 when she joined the Environmental Research unit at the Brazilian Agricultura Research Agency (Embrapa). She focused her research on the environmental impact of GMOs.

José Maria F. J. da Silveira Agronomist, PhD in Economics, University of Campinas Faculty of the Institute of Economics, University of Campinas, Researcher at the Agricultural and Environmental Research Center - NEA and member of the Study Group in Research Organization and Innovation, GEOPI. Counselor of the Biotechnology Information Council-Brazil. 